\title{
Quelques caractéristiques de l'écoulement en conduite d'un intérêt pratique; méthode approchée de mesure de débit
}

\section{Some pipe flow characteristics of engineering interest and an approximate method of discharge measurement}

\author{
PAR LEWIS F. MOODY (1) \\ Prainfield, N.I. \\ English synopsis p. 311
}

\begin{abstract}
On a coulume, dans lenseignement de lHydranlique et de la Mécanique des fluides émentaires, de traiter l'écoulement dans les conduites. au début, comme si la vilesse itait aniforme dans toute la section; et bien que les théories modernes du frottement des fluiles soicnl exposées par la suite, rewes sont cenx de nos ouvrages ani les appliquent is ane rectificalion complete des hypotheses initiales. Nous nous proposons de passer en revale, pour une conduile rectiligne de section uniforme en régine permanent, les conséquences de la distribution réelle des vitesses sur Ia charge dynamique, sur la quantité de mouvement et sur le rapport entre li vitesse moyenne el la vitesse maximum. Lusage, pour une mesure approximative du débit des condaites, du rapport de la vitesse moyenne a la vitesse maximum, appelé «pipe factor $*$ dans le jargon technique américain *, fait dautre part lobjel d'unc étude plus approfondie que dans les exposés antérieurs.
\end{abstract}

Dans le domaine du frollement dans les conduiles, les dóveloppements reeenls de la mécarnique des fluides ont conduit a des relations qui, quoique loujours essentiellemenl empiriques,

\footnotetext{
* Nat - En francais, nous ne comnatsons pas de terme utilisé. Pent-être pourrat-on proposer l'expression « coefficient de vitesse $》$
}

It is castomary, in teaching elementary hydraulics, and fluid mechanics, to treat pipe flow, at first, as if the velocity were uniform over the cross-seclion; and although the modern theories of fluid friction are later explained, few of our text-boolss apply them to correct the initial assumptions completely. The effect of the actual velocity distribution in a straight uniform pipe, with established regime of flow, on the velocity head, momentam, and relalion between mean and maximum velocity will be reviewed here. The use of the mean-to-maximum velocity ratio, the so-called "pipe factor", for an approximate measurement of pipe discharge, is worked out more fully than in previous discussions.

The fluid mechanies of pipe friction has for some lime been sufficiently developed to yield relations which, while still highly empirical, have been adequate for engineering purposes. 'These

(1) Professor of Hydraulic Engineering, Erneritus, Prinecton University. Consulting Engineer, Worthington Pump \& Mchy. Corp., Harrison, N.J. 
s'adaptent bien aux besoins de l'ingénieur. C'est grâce à ces relations que l'on a pu évaluer les coefficients de frottement couramment donnés maintenant par des abaques (2) (3).

Il arrive que, pour résoudre certains problèmes, l'ingénieur soit contraint de faire appel à des facteurs caractéristiques autres que le coefficient de frottement; par exemple, Iorsqu'on applique la formule de Bernovar à l'écoulement en conduite, il est bien connu que la charge $d y-$ namique appelée communément $V^{2} / 2 g, V$ étant la vitesse moyenne, devrait strictement être écrite $\infty \frac{V^{2}}{2 g}$ pour tenir compte de la courbe de distribution de vitesse. Le coefficient que l'on pourrait appeler coefficient d'énergie cinétique, ne dépasse l'unité que de 5 ou $10 \%$ pour un régime permanent dans une conduite de section uniforme rectiligne, il est en général négligé; mais puisqu'il peut être évalué, on peut tout aussi bien en tenir compte. Le surcroît de précision qui en résulte peut souvent en valoir la peine, par exemple dans l'évaluation de l'énergic cinétique dissipée à l'extrémité aval d'une conduite lorsque le $\mathrm{V}^{2} / 2 g$ a une valeur appriciable vis-à-vis de la perte de charge par frottement.

Un autre facteur caractéristique dont on peut avoir besoin est le coefficient de quantité de mouvement désigné dans la suite par $\beta$. Lorsqu'on estime la réaction d'un jet noyé issu d'une conduite d'une longueur suffisante pour qu'on parvienne à un écoulement normal, la force n'est pas strictement égale a $\bar{\omega} Q \frac{V}{g}$ (๘) étant le poids spécifique et $Q$ le débit), mais est un peu plus grande et peut être exprimée par $\beta \bar{\sigma} Q \frac{V}{g}$ ou $\beta \approx A \frac{V^{2}}{g}$ (A étant la section de la conduite) (4) (5).

Le troisième coefficient caractéristique que l'on discutera ici est le rapport de la vitesse moyenne à la vitesse maximum appelé « coefficient de vitesse » que l'on écrira $f_{n}$. Linverse de ce rapport :

$$
\frac{1}{f_{1}}=\frac{v_{\operatorname{mix}}}{\mathrm{V}}
$$

sera aussi utilisé et sera noté $\gamma$. Ie « coefficient de vitesse $»$, qui était analysé l'an dernier par le professeur Folsom et le professeur Iversen (6), s'avère utile dans certaines applications telles que l'évaluation du débit par une simple mesure de vitesse sur l'axe de la conduite, méthode exposée par Folsom et IVERsen et assez largement développée plus loin.

Ces facteurs dépendent tous de la courbe de

(3) La référonce 2 ast aletuellement épuiséc; les abacues ct autres donnees utiles se trouvent dans" Standards of hyclaalic Institute "1949 dans lesquels les abaques sont l'cuve du Prof. C. P. KrTtrisdar. relations have been utilized to evaluate friction factors, which are now readily available from charts $(2,3)$.

Occasionally, engineering problems require tho use of other characteristies besides the friction factor. For example, in applying the Bervould formula for pipe flow, it is well known that the velocity head term commonly written $\mathrm{V}^{2} / 2 g, \mathrm{~V}$ being the mean velocity, should strictly be written $\approx V^{2} / 2 g$ to take account of the curve of velocity distribution. Since $\alpha$, which may be termed the kinetic energy factor, exceeds unity by only 5 or 10 percent, for a completely established régime of flow in a straight uniform pipe, it is commonly neglected; but since it can be easily evaluated it can just as well be included. The increased accuracy may often be worthwhile, as in figuring the kinetic energy rejected at the end of a pipe when the velocity head is appreciable in comparison with the friction loss.

Another characteristic which may occasionally be needed is the momentum factor, which will be denoted $\beta$. In figuring the reactive force of the jet discharging (submerged) from a pipe of sufficient length to provide normal flow, the force is not striclly equal to $\mathrm{wQV} / \mathrm{g}(\mathrm{w}=$ specific weight in lbs. per cu. ft., $Q=c u$. ft. per sec. discharged) but is somewhat greater and can be expressed $\beta w Q V / g$ or $\beta w A V=/ g$ (A being the area of the pipe cross-section $(4,5)$.

The third characteristic to be discussed here is the so-called "pipe factor" or "velocity factor" , the ratio of mean to maximum velocity, which will be denoted $f_{j}$. The inverse of this

$$
\frac{1}{f_{p}}=\frac{v_{\ln : 1 x}}{\mathrm{~V}}
$$

will also be used and denoted $\%$. The pipe factor, which was discussed last year by Professor Forsom and Professor Iversen (6), is useful in such applications as approximating the discharge by means of a single velocity measurement at the pipe axis, a method treated by Folsom and IVERSEN and further developed below.

These factors are all dependent on the curve of velocity distribution across the pipe. At very

(2) "Friction Factors for Pipe Flow", by L. F. Moovx, Tians. A.S.M.E., vol. 66,1944

(3) Since reference 2 is at present out of print, the charts and other useful data may be found in "Standards of the Hydraulic Institute", 1949, in which the charts have been reconstructed by Prof. C. P. KirTrencix.

(4) "The Kinetic Encrgy and Momentum Correction Factors for Pipes and Open Channels of Great Width", by V. L. STrerere, Civil Engineering, vol. 12, n" 4,1942 . (5) "Steady Flow in Pipes and Conduils", by V. I. Srmester, th Hydraulies Conference, Iowa Inst, of Hydratic Research, June 12-15, 1949.

(6) "Pipe Factors for Quantily Rale Flow Neasulements with pitol Tubes", by R. G. Forsom and H. W. Ivensen, A.S.M.E. Annual Mecting, Nov, 29-Déc. 3, 1948. 
repartition de vitesse dans la conduite. Aux vilesses très faibles dans les petites conduites, ou avec des fluides de viscosité élevée, à des nombres de Reynolds plus petits que 2000, l'écoulement est permanent et entièrement régi par les forces de viscosité. Cet écoulement laminaire est facilement analysé par des méthodes rationnelles, la courbe de vitesse étant la parabole :

$$
v=v_{\max }\left(1-\frac{r^{2}}{r_{0}^{2}}\right)
$$

dans laquelle $v$ est la vitesse pour un rayon $r$, $v_{\operatorname{mix}}$ la vitesse au centre et $r_{0}$ le rayon de la conduite.

Aux vitesses courantes, dans les conduites de section usuelle, l'aspect de l'écoulement se présente de la facon suivante : l'écoulement laminaire décrit ci-dessus ne subsiste que dans un film très mince au voisinage de la paroi, film entourant une zone centrale envahie par des tourbillons (turbulence), dans laquelle l'écoulement n'est plus permanent, les vitesses plus parallèles et où l'on ne peut plus parler de régime. laminaire. Aux grandes vitesses, dans les conduites rugueuses, le film laminaire est brisé et l'écoulement est entièrement turbulent.

Dans le cadre de la présence étude, le film laminaire se trouve, dans les conditions techniques usuelles, si mince que sa contribution au débit d'ensemble de la conduite est négligeable et qu'il ne constitue qu'une portion insignifiante de la courbe de vitesse; aussi nous admettrons, par la suite, que la distribution de vitesse est celle d'un écoulement complètement turbulent. En rappelant brievement les travaux de Pranote et de Karman (7), l'écoulement peut être décrit comme la superposition d'un écoulement permanent parallele, dont la vitesse moyenne dans le temps a une valeur $v$ pour le rayon $r$, et d'un champ de turbulence introduisant des fluctuations de vitesse : $v^{\prime}$ axiale, et $u^{\prime}$ radiale. Cette turbulence provoque un mélange continuel de courants adjacents et un transfert de quantités de mouvements d'une ligne de courant à l'autre; un faible degré de turbulence suffisant à produire des efforts tangentiels importants et un aplatissement de ia courbe de distribution de vitesse.

Karman et Prandre, en prenant $v^{\prime}$ proportionnel à la différence de valeur de $v$ en des points séparés par une distance $l$, intitulée «longueur de mélange », et en supposant $u^{\prime}$ du même ordre de grandeur que $v^{\prime}$ et proportionnel à ce dernier, parviennent à une relation simple donnant l'effort tangentiel :

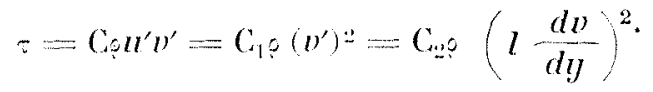

Aux points voisins de la paroi lorsque low velocities in small tubes, or with fluids of high viscosity, with Reynolds numbers less than 2,000 , the flow is steady under the control of viscous forces. This "laminar" flow is readily analysed by rational methods, the velocity curve being the parabolit :

$$
v=v_{\max }\left(1-\frac{r^{2}}{r_{0}^{2}}\right)
$$

in which $v$ is the velocity at any radius $r, v_{\operatorname{mix}}$ the center velocity and $r_{0}$ the pipe radius.

At ordinary velocities in pipes of usual sizes, the flow may be pictured as a thin boundary layer in which the laminar flow just described still persists, surrounding a central zone permeated by eddies or turbulence in which the flow is no longer steady or in parallel lines or laminae. At high velocities in rough pipes the laminar layer is broken up and the entire flow is turbulent.

For our present purposes, the laminar boundary layer, when it exists, is, under usual engincering conditions, so thin that it contributes a negligible amount to the pipe discharge and forms an insignificant portion of the velocity curve; so that for out present purposes the velocity distribution can be based on completely turbulent flow. Briefly reviewing the PravdrtKarman (7) analysis, the flow may be described as steady flow in parallel lines with time-average velocity $v$ at radius $r$, with a superposed field of turbulence or eddies introducing fluctuating axial velocity $v^{\prime}$ and radial velocity $u^{\prime}$. This turbulence causes a continual mixing of adjacent flows and transfer of momentum across the flow lines, even a small degree of turbulence producing a strong shearing stress and a flat-topped curve of velocity distribution.

Karman and Prandth, by taking $v^{\prime}$ proportional to the difference in the $v$ velocities at points separated by a distance $l$, the "mixing length ", and considering $u^{\prime}$ to be of the same order of magnitude as $v^{\prime}$ and proportional to it, arrived at a simple relation giving a shearing stress :

$$
\tau=\mathrm{C}_{\rho} u^{\prime} v^{\prime}=\mathrm{C}_{1}{ }\left(v^{\prime}\right)^{2}=\mathrm{C}_{2 \rho}\left(l \frac{d v}{d y}\right)^{2}
$$

At points close to the pipe wall, with $y=r_{0}-r$

(7) "Neuere Ergebnisse der Turbulenz Forschung", by L. PrANDTL, Z. V. d. I., 1933, p. 105. 
$y=r_{0}-r$ est petit par rapport à $r_{0}$, les conditions se rapprochent de l'écoulement sur une surface plane et Prandth suppose alors que $l$ est proportionnel à $y$ el :

$$
\tau=\tau_{0}=l * v_{0}\left(y \frac{d v}{d y}\right)^{2}
$$

oì $\tau_{0}$ est l'effort tangentiel à la paroi. Il ressort de là que, près de la paroi, nous avons :

$$
d v=\frac{1}{k} \sqrt{\frac{\tau_{0}}{\rho}} \frac{d y}{y} .
$$

Il s'avère que cette relation coincide de tres près non seulement avec les conditions régnant au voisinage de la paroi, mais aussi avec ce qui se passe dans toute la section jusqu'à l'axe, et il en résulte une courbe de répartition de vitesse serrant de très près les observations de NwuRADSE entre autres; il s'avire, de plus, que ces résultats concordent mieux avec les expériences ci-dessus que des expressions plus fouillées comme celle de VON Karman. Si l'on integre :

$$
\begin{aligned}
& v=v_{\max }-\frac{1}{l_{i}} \sqrt{\frac{\tau_{0}}{0} \ln \frac{r_{0}}{!}} \\
& v=v_{\max }-\frac{1}{l_{i}} \sqrt{\tau_{0} \ln \frac{r_{0}}{r_{0} \cdots r^{\prime}}}
\end{aligned}
$$

Dans ces expressions, $k$ est la constante universelle de Núuranse pour laquelle nous prendrons la valeur de 0,40 , et p est la masse spécilique du fluide (8) (9).

La thérie si brièvement résuméc est, presque à chaque pas, sujette à discussion. Par exemple, est-ce que la relation reliant $u^{\prime}$ à $v^{\prime}$ ne devait pas ètre une fonction de $r^{r}$ puisque $u^{\prime}$ doit s'anmuler le long de la paroi? Est-ce que la longueur $l$ ne devrait pas ètre prise comme une fonction non seulement de $y$, mais aussi de $2 r_{0}-\eta$, distance à la paroi opposée? L'expression de $v$ est evidemment très empirique. Sa forme differe, par exemple, de celle qu'aflecte le résultat d'une analyse des efforts sur un disque tommant, où une solution rationnelle complite donne des eforts qui ne sont pas des fonetions de $r$ mais de $r \%$ si bien qu'ils sont symétriques pour $+r$ ou $r . . r$. Notre formule pour $b$ ne s'applique que de $r=r_{0}$ a $r=0$ et ne signifie rien pour les raleurs négatives de $r$ ou pour $y>r_{0}$; et la courbe a une pente légère au niveau de l'axe. Il n'en reste pas moins que les écarts avec les vitesses mesurees sont fables et surtout localiseses dans la région voisine de laxe qui ne participe que pour une laible part au débit.

1! est probable que lon trouvera une expression plus rationnclle et en accord plus strict avec l'expérience. Le professeur Wang (10) a mis au small compared to $r_{0}$, conditions approach the llow past a plane surface, and here Plinnot argued that $l$ should be proportional to $y$ and :

$$
\tau=\tau_{0}=k: 0\left(y \frac{d v}{d y}\right)^{2}
$$

$\tau_{0}$ being the wall shearing stress. From this procedure we have near the wall :

$$
d v=\frac{1}{k} \sqrt{\frac{\tau_{0}}{\rho}} d y
$$

It was found that this relation was in close agreement not only with conditions near the wall but all the way to the axis, and that it resulted in a velocily curve closely approximating the observations of Nrouradse and others; and was in better agreement with them than were the more elaborate expressions of VON KanwiN and others. Integrating :

$$
v=v_{1: i x} \cdots \cdots \cdot \frac{1}{k} \sqrt{\frac{\tau_{0}}{\rho}} \ln \frac{r_{0}}{y}
$$

or :

$$
n=v_{\max }-\frac{1}{k} \sqrt{\frac{\tau_{0}}{\rho}} \ln \frac{r_{0}}{r_{0}-r}
$$

Here $k$ is Nikuradse's universal constant, for which we shall use his value of 0.40 , and $\rho$ is the mass density of the fluid $(8,9)$.

The development so briefly outlined is open to argument at almost every step. For example, should not the ratio of $u^{\prime}$ to $v^{\prime}$ be a function of $r^{\prime}$, since $u^{\prime}$ must vanish at the wall? Should not $l$ be taken as a function not only of $y$ but also of $2 r_{0}-y$, the distance from the opposite wall? The expression for $v$ is evidently highly empirical. It is unlike the results of the stress analysis of a revolving disk, for example, for which a completely rational solution gives the stresses as functions not simply of $r$ but of $r^{2}$, so that they are symmetrical for plus and minus $r$. Our formula for $v$ can be applied only from $r=r_{0}$ to $r=0$, and fails for negative $r^{\prime}$ s or for $y>r_{6}$; and the curve has a slight slope at the axis. Nevertheless the deviations from measured velocities are slight and mainly in the region near the axis, involving only a very small part of the discharge.

It is probable that a more rational expression in still closer agreement with observations will ultimately be found. Professor Wava (10) has

(8) "The Hechanies of Turbulent flow", by $B . A$. Baklimertik, page 68 .

(9) "Flud Mechanics lor Ilydratic Engincers", by Hunler ROUSE.

(10) "On the Velocity Distribution of "urbulent flow in Pipes and Channels of Constant Cross-Section", by Chi-Teh WANa, Jomrnal of Applied Mechanies, A.S.M.E., June 1946 , p. A-85. 
point une expression empirique, mais sa forme transcendante est si complexe qu'elle ne paraît pas intéressante dans la pratique; elle semble souffrir d'un manque de symétrie comme celle de Prandt et ne parait pas donner la solution définitive. Aussi imparfaite qu'elle apparaisse à ceux qui cherchent la perfection, la formule de Prandotr est bien à l'intéricur du domaine de précision justifié par les données expérimentales et elle constitue une relation simple et satisfaisante pour les applications pratiques.

Reprenant maintenant les différents facteurs mentionnés ci-dessus, la vitesse moyenne peut être trouvée en intégrant les débits partiels à travers les surfaces annulaires élémentaires, $2 \pi \int v r^{\prime} r$, et en divisant par la section de la conduite $\pi r_{0}^{2}$, le « coefficient de vitesse » est alors :

$$
l_{\mu}=\frac{\mathrm{V}}{v_{\max }}=\frac{2 \cdot \int_{0}^{v_{0}} v r d r}{v_{\max } r_{0}^{2}}
$$

un coefficient commode est l'inverse de $f_{p}$ :

$$
y=\frac{1}{f_{p}}=\frac{v_{\max }}{Y}
$$

La quantité de mouvement traversant en une seconde une surface annulaire est :

$$
\frac{\varpi(d q) v}{g}=\frac{\pi v^{2}(2 \pi r d r)}{g}
$$

qui, intégré, peut s'exprimer par :

$$
\beta \omega \mathrm{A} \frac{\mathrm{V}^{2}}{g}=\beta \bar{\omega} V^{2} \frac{\pi r_{0}{ }^{2}}{g}
$$

le coefficient de quantité de mouvement est donc:

$$
\beta=\frac{2 \int_{0}^{r_{0}} v^{2} r d r}{V^{2} r_{0}^{2}}
$$

L'énergie cinétique du conrant traversant une surface annulaire est :

$$
\frac{\pi(d q) v^{2}}{2 g}=\frac{\pi v^{*}(2 \pi r d r)}{2 g}
$$

dont l'intégrale correspond à l'expression :

$$
\alpha \overline{\mathrm{w}} \mathrm{Q} \frac{\mathrm{V}^{2}}{2 g}=\alpha \bar{\omega} \mathrm{V}: \pi r_{0}^{2} / 2 g
$$

d'ò̀ le coefficient d'ónorgie cinćlique :

$$
\alpha=\frac{2 \int_{0}^{r^{\prime \prime}} v^{n} r d r}{\mathrm{~V}^{3} r_{0}{ }^{2}}
$$

developed an empirical expression, but it is of such complex transcendental form that it is not attractive for engineering use, and it appears to suffer from lack of symmetry like the PRANDTL. form and does not look like the ultimate answer. For all its shortcomings for the perfectionist, the PrandTL equation is well within the degree of accuracy justified by the test data and is a simple and satisfactory relation for engineering applications.

Now taking up the various factors mentioned above, the average velocity is found by integrating the discharges through the differential annular strips, $2 \pi \int v r d r$, and dividing by the pipe area $\pi r_{0}{ }^{2}$ giving the pipe factor :

$$
f_{n}=\frac{\mathrm{V}}{v_{\max }}=\frac{2 \int_{0}^{r_{0}} b l d r}{v_{\max } r_{0}{ }^{2}}
$$

A convenient factor is the reciprocal of $f_{p}$, the velocity factor :

$$
\gamma=\frac{1}{f_{p}}=\frac{v_{\max }}{\mathrm{V}}
$$

The momentum of the flow per second through an annular strip is :

$$
\frac{\mathrm{w}(d q) \nu}{g}=\frac{\mathrm{w} v^{2}(2 \pi r d r)}{g}
$$

which when integrated may be expressed as :

$$
\beta w A \frac{\mathrm{V}^{2}}{g}=\beta \mathrm{w}^{2} \frac{\pi r_{0}^{2}}{g}
$$

Hence the momentum factor is :

$$
\beta=\frac{2 \int_{0}^{r_{0}} v^{2} r d r}{V^{2} r_{0}^{2}}
$$

The kinetic energy of the flow through an annular strip is :

$$
\frac{\mathrm{w}(d q) v^{2}}{2 g}=\frac{\mathrm{w} v^{: 3}(2 \pi r d r)}{2 g}
$$

the integral of which may be expressed as :

$$
\alpha \mathrm{wQ} \frac{\mathrm{V}^{2}}{2 g}=\alpha \mathrm{wV} \pi r_{0}{ }^{2} / 2 g
$$

Hence the kinetic energy factor is :

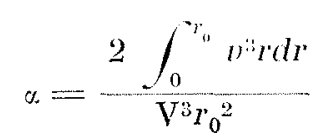




\section{Ecoulement laminaire}

Pour l'écoulement laminaire, si l'on tient compte de ce que :

$$
v=v_{\max }\left(1-\frac{r^{2}}{r_{0}^{2}}\right)
$$

nous obtenons pour les relations précédentes :

$$
f_{p}=1 / 2 \text { et } \gamma=2 \text {. }
$$

Si l'on pose:

$$
v=2 V\left(1-\frac{r^{2}}{r^{2}}\right)
$$

on trouve :

$$
\beta=4 / 3 \text { et } \alpha=2 \text {. }
$$

\section{Ecoulement turbulent}

Ians la relation de Prandto :

$$
v=v_{\max }-\frac{1}{k} \sqrt{\frac{\tau_{0}}{\rho}} \ln \frac{r_{0}}{y}
$$

nous pouvons exprimer $\tau_{0}$, l'effort tangentiel à la paroi, en fonction du coefficient de frottement $f$, en écrivant qu'il y a équilibre entre l'ensemble des forces de frottement sur la paroi et la chute de pression le long de la conduite pour un $\mathrm{cy}$ lindre élémentaire de fluide; ceci dome :

$$
\sqrt{\frac{\tau_{0}}{5}}=V \sqrt{\frac{1}{8}} \text {. }
$$

Si l'on appelle :

$$
a=\frac{1}{k} \sqrt{\frac{\tau_{0}}{?}}=\frac{V \sqrt{f}}{0,40 \sqrt{8}}=0,884 \mathrm{~V} \sqrt{f}
$$

la vitesse est :

$$
v=v_{\max }-a \ln \frac{r_{0}}{y} .
$$

En tenant compte de cetle cxpression et en posant $r=r_{0}-y$, la vitesse moyenne est donnée par :

$$
\begin{aligned}
V=\frac{2}{r_{0}^{2}} \int_{0}^{r_{0}} \operatorname{vrdr}= & v_{\min \mathrm{x}}-a \ln r_{0} \\
& +\frac{2 a}{r_{0}^{2}} \int_{0}^{r_{n}}\left(r_{0}-y\right) \ln y d y .
\end{aligned}
$$

En intégrant le dernier terme et au cours des intégrations requises pour $\beta$ et a, on trouvera que la limite inférieure donne des termes de la forme $y^{m}(\ln y)^{n}$ qui, pour $y=0$, sont soit nuls, soit indéterminés. Les termes indéterminés penvent c̀tre résolus par différentiations sucessives et sont tous trouvés se réduire à zéro.

\section{LAMINAR FLOW}

For laminar flow, inserting in these expressions :

$$
D=v_{\max }\left(1-\frac{r^{2}}{r_{0}^{2}}\right)
$$

we oblain :

$$
l_{p}=1 / 2 \text { and } \gamma=2 \text {. }
$$

Putling :

$$
v=2 \mathrm{~V}\left(1-\frac{r^{2}}{r^{2}}\right),
$$

we find :

$$
\beta=4 / 3 \text { and } \alpha=2 \text {. }
$$

\section{Tunbulent Flow}

In the PIRANoth relation :

$$
v=v_{\max }-\frac{1}{k} \sqrt{\frac{\tau_{0}}{\rho}} \ln \frac{l_{0}}{y}
$$

we can express $\tau_{0}$, the wall shearing stress, in terms of the friction factor $f$ by writing a force balance between the total wall shearing force and the pressure drop along the pipe applied to an elementary cylinder of fluid, giving :

$$
\sqrt{\frac{\tau_{0}}{9}}=V \sqrt{\frac{f}{8}}
$$

Then calling :

$$
a=\frac{1}{k} \sqrt{\frac{\tau_{0}}{\rho}}=\frac{V \sqrt{f}}{0.40 \sqrt{8}}=0.884 \mathrm{~V} \sqrt{f}
$$

the velocity is :

$$
v=v_{\max }-a \ln \frac{r_{0}}{y} .
$$

Inserting this expression and putting :

$$
r^{\prime}=r_{0}-y
$$

the mean velocity is given by :

$$
\begin{aligned}
V=\frac{2}{r_{0}^{2}} \int_{0}^{r_{0}} \text { ord } & =v_{\max }-a \ln r_{0} \\
& +\frac{2 a}{r_{0}{ }^{2}} \int_{0}^{r_{0}}\left(r_{0}-y\right) \ln y d y .
\end{aligned}
$$

In integrating the last term, and in the integrations required for $\beta$ and $\alpha$, it will be found that the lower limit results in terms of the form $y^{n}(\ln y)^{n}$ which wilh $y=0$ are either zero or indeterminate. The indeterminate terms can be resolved by successive differentiation and are all found to reduce to zero. 
L'intégration précédente (11) donne :

$$
\mathrm{V}=v_{\max }-\frac{3}{2} a=v_{\max }-1,326 \mathrm{~V} \sqrt{f}
$$

si bien que :

$$
v_{\max }=\mathrm{V}(1+1,326 \sqrt{f}) ; \quad \gamma=1+1,326 \sqrt{f}
$$

et le « coefficient de vitesse »:

$$
f_{\mathrm{p}}=\frac{1}{1+1,326 \sqrt{f}}
$$

Le facteur a ci-dessus peut s'exprimer par :

$$
a=\frac{2}{3}(y-1) \mathrm{V} .
$$

On peut remarquer que le rayon pour lequel la vitesse locale est égale à la vitesse moyenne, $v=\mathrm{V}$, vaut 0,777 fois le rayon de la conduite.

Le coefficient de quantité de mouvements $\beta$ peut être exprimé en tenant compte de :

$$
v=v_{\max }-a \ln \frac{r_{0}}{\eta} \quad \text { et } \quad r=r_{0}-y
$$

dans l'expression :

$$
\beta=\frac{2}{\mathrm{~V}^{2} r_{0}^{2}} \int_{0}^{r_{0}} \nu^{2} r d r .
$$

Cette expression peut être développée et intégrée, les termes relatifs à la limite inférieure étant, comme déjà mentionné, nuls ou indéterminés se réduisant à zéro par différentiations successives.

I'intégration donne:

$$
\beta=\frac{v^{2}{ }_{\max }}{\mathrm{V}^{2}}-\frac{3 v_{\max } a}{\mathrm{~V}^{2}}+\frac{7}{2} \frac{a^{2}}{V^{2}}
$$

et in tenant compte de :

$$
a=\frac{2}{3}(y-1) \mathrm{V}
$$

ceci se réduit à :

$$
\beta=1+\frac{5}{9}(\gamma-1)^{2}
$$

ou, en fonction du coefficient de frottement, compte tenu de :

$$
\begin{gathered}
\gamma=1+1,326 \sqrt{f} \\
\beta=1+0,977 \mathrm{f} .
\end{gathered}
$$

The above integration (11) gives:

$$
\mathrm{V}=v_{\max }-\frac{3}{2} a=v_{\max }-1.326 \mathrm{~V} V
$$

so that :

$$
v_{\max }=\mathrm{V}(1+1.326 \sqrt{f}) ; \quad \gamma=1+1.326 \sqrt{f},
$$

and the pipe factor :

$$
f_{\mathrm{p}}=\frac{1}{1+1,326 \sqrt{f}}
$$

The above coefficient $a$ can be expressed :

$$
a=\frac{2}{3}(\gamma-1) \mathrm{V} .
$$

It may be noted that the point where the local velocity is equal to the mean velocity, $v=\mathrm{V}$, occurs at a radius of 0.777 times the wall radius.

The momentum factor $\beta$ may be derived by inserting :

$$
v=v_{\max }-a \ln \frac{r_{0}}{y} \quad \text { and } \quad r=r_{0}-y
$$

in the expression :

$$
\beta=\frac{2}{V^{2} r_{0}^{2}} \int_{0}^{r_{0}} \nu^{2} r^{\prime} d r .
$$

This can be expanded and integrated, the lower limit terms, as mentioned, being either zero or indeterminate, reducing to zero by successive differentiation.

The integration gives :

$$
\beta=\frac{v^{2} \max }{V^{2}}-\frac{3 v_{\max } a}{V^{2}}+\frac{7}{2} \frac{a^{2}}{V^{2}}
$$

and inserting :

$$
a=\frac{2}{3}(\vartheta-1) \mathrm{V}
$$

this reduces to :

$$
\beta=1+\frac{5}{9}(\gamma-1)^{2}
$$

or in terms of the friction factor, inserting :

$$
\begin{gathered}
\gamma=1+1.326 \sqrt{f} \\
\beta=1+0.977 \mathrm{f} .
\end{gathered}
$$

(11) "The Mechanics of Turbulent Flow", by B. A. BaKHMETEFF, see Eq. (116), p. 70. 
Par un raisonnement analogue, le coefficient d'énergie cinétique peut être exprimé en tenant compte de:

$$
v=v_{\max }+a \ln \frac{r_{0}}{y} \text { et de } r=r_{0}-y
$$

dans :

$$
\alpha=\frac{2}{V^{3} r_{0}^{2}} \int_{0}^{r^{\prime \prime}} v^{3} r d r
$$

Comme ci-dessus, les termes relatifs à la limite inférieure s'amnulent et l'intégration donne (12):

$$
\alpha=1+\frac{2}{3}(\%-1)^{2}\left(\frac{7}{2}-\gamma\right)
$$

ou en fonction du coefficient de frottement :

ou :

$$
\alpha=1+2,93 f(1-0,53 \sqrt{f})
$$

$$
\alpha=1+2,93 f-1,55 f \%
$$

Dans la pratique, du moins pour $f \leqslant 0,04$, il est suffisamment exact dutiliser :

$$
x=1+2,7 f
$$

Les intégrations ci-dessus sont relativement longues, les développements donnent 12 termes pour $\beta$ et 16 termes pour $\%$, termes dont la plupart se développent encore en cours d'intégration : il y a donc là de nombreuses causes d'erreurs. A titre de contrôle, les intégrations peuvent ètre faites en prenant $v$ au lieu de $y$ comme variable et en posant :

$$
y=\frac{r_{0}}{\varepsilon^{\gamma v / a}} \varepsilon^{v / a}
$$

comme contrôle supplémentaire * peut être intégré graphiquement avec un planimetre.

Par une curieuse coïncidence, pour l'écoulement laminaire avec $\gamma=2$, la relation de l'écoulement turbulent dérivée exactement donne $\alpha=2$, en accord avec la relation d'écoulement laminaire. Ce résultat n'est pourtant qu'une curiosité puisque la relation de l'écoulement turbulent est seulement une approximation où l'on néglige le film laminaire. Un «.coefficient de vitesse 》 de $1 / 2$ ou un $\gamma=2$ ne peut ètre obtenu à partir des formules de l'écoulement turbulent que lorsque te coefficient de frottement $f$ est énorme et tout a fait en dehors des limites de la pratique; dans ces conditions, l'équation de Prandetr pour $v$ donne des vitesses négatives à une certaine distance de la paroi et cesse d'avoir une valeur pralique.

(12) Le prof. C. P. Kurtredge nous informe que le prof. J. O. Smith, University of Illinois, a etudie ce coefficient dans un travail non publié du 20 dec. 1940 et qu'il obtient : en utilisant nos notations :

$$
a=1+\frac{5}{3}(\gamma-1)^{2}-\frac{3}{2}(\gamma-1)^{3}
$$

qui se reduit à la forme ci-dessus.
Following a similar procedure, the kinetio energy lactor is derived by inserting :

$$
v=v_{\operatorname{mix}}+a \ln -\frac{y}{r_{0}} \text { and } r=r_{0}-y
$$

in :

$$
\alpha=\frac{2}{V^{3} r_{0}^{2}} \int_{0}^{r_{0}} v^{3} r d r
$$

As before, the lower limit terms are all found to vanish; and the integration gives (12) :

$$
\alpha=1+\frac{2}{3}(y-1)^{2}\left(\frac{7}{2}-\eta\right)
$$

or in terms of the friction factor :

$$
x=1+2.93 f(1-0.53 \sqrt{f})
$$

or :

$$
x=1+2.93 f-1.55 f \%
$$

For practical purposes, at least up to $f=0.04$, it is close enough to use :

$$
\alpha=1+2.7 f
$$

Since the above integrations are rather lengthy, the expansions yielding 12 terms for $\beta$ and 16 terms for $\alpha$, most of which expand further on integration, there are ample opportunilies for error. As a check the integrations may be carried out in terms of $v$ instead of $y$ as the variable, putting :

$$
y=\frac{r_{0}^{r}}{\varepsilon^{\gamma v / a}} \varepsilon^{v / a}
$$

As a further check, \& may be integrated graphically by planimeter.

It is a curious coincidence that for laminar flow, with $\gamma=2$, the turbulent flow relation just derived gives $a=2$, in agreement with the laminar flow relation. This result is however a mere oddity, since the turbulent flow relation is only an approximation, neglecting the laminar boundary layer. A pipe factor of $1 / 2$ or $\gamma=2$ is obtainable from the turbulent flow formula only when the friction factor $f$ is enomous and far beyond the practical range, and under these conditions the Prandtr equation for $v$ gives negative velocities for an appreciable distance from the pipe wall, and ceases to be practical.

(12) Professor C. P. KitTredie advises that Professor J. O. Smith, University of Illinois, worked out this factor in an unpublished paper of Dec. 20 , 1940, obtaining in my notation :

$$
a=1+\frac{5}{3}(\gamma-1)^{2}-\frac{2}{3}(\gamma-1)^{a}
$$

which reduces to the above form. 
Les relations oblenues ici onl ble mises sous lorme de tableaux el de graphique dans les figures 1 et 2. Jos valeurs du coefficient de frotte-
The relations here derived are tabulated and plotted in Figs. 1 and 2 . The values of the friction factor $f$, on which the various factors

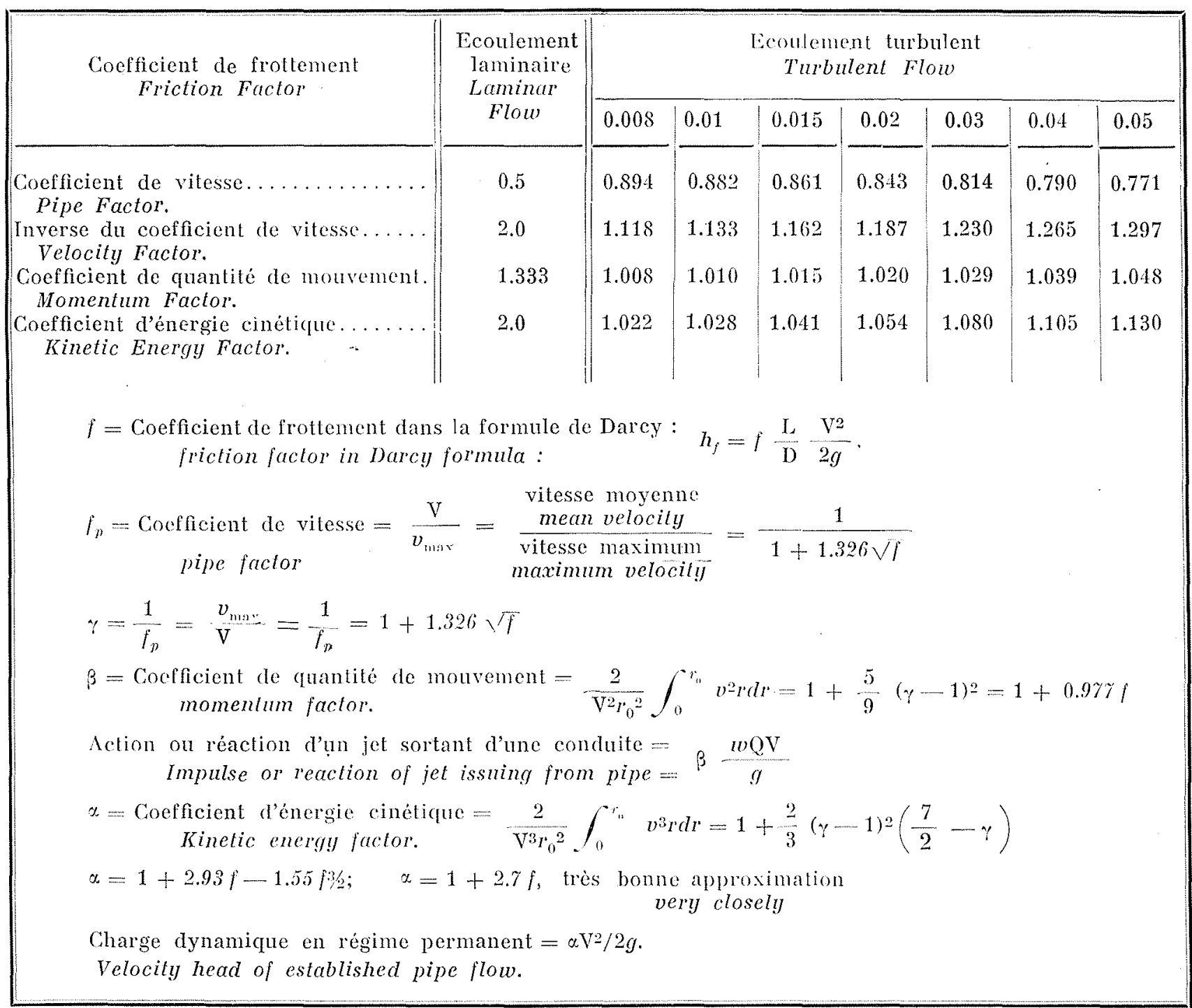

FIG. 1

ment f, qui dépend de nombreux facteurs, seront trouvées soit en se reportant aux références (2) et (3), soit à partir de la formule approximative suivante :

$$
f \cong 0,0055\left[1+\left(20.000=/ D+10^{3} /(\Omega) 1 / 3\right]\right.
$$

pour $4.000<\Omega<10^{7}$ et $\varepsilon / \mathrm{D}<0,01$ on $f<0,05$;

(R étant le nombre de Reynolds $\frac{V D}{v}$, et $\approx$ la rugosité absolue avec les valeurs suivantes recommandées, en $1 / 10$ de $\mathrm{mm}$. depend, may be found from the charts of references 2 or 3 , or by an approximate formula (13)

$$
f \cong 0.0055\left[1+\left(20,000=/ D+10^{\mathrm{r} / R}\right) / 3\right]
$$

for $4,000<\Re<10^{7}$ and $\varepsilon / D<0.01$ or $f<0.05$; in which $R$ is Reynold's Number, $\frac{V D}{y}$, and $s=$ absolute surface roughness, with the following recommended values in feet :

(13) "Approximale Formula for Pipe Friclion Factors" by 1.. F. Moody, Mechanical Engineering, vol. 69, 1947, ip. $1005-6$. 


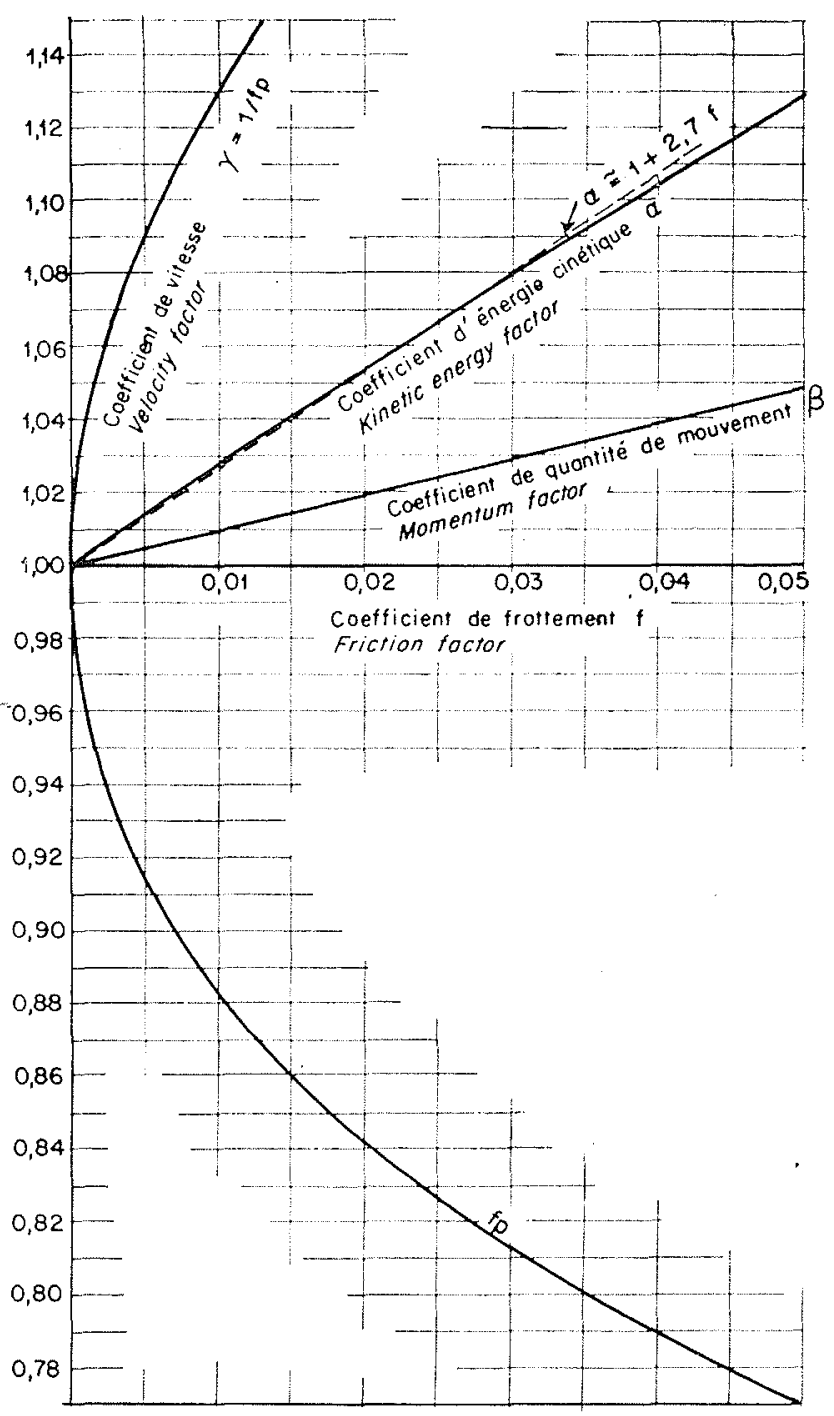

FIG. 2

Tuyaux étirés, en laiton, plomb, verre, ciment centrifugé, avec revêtement bitumineux, Transite $\left(^{*}\right)$, etc. 0,015

Acier ordinaire ou fer forgé....... 0,45

Fonte revêtue................ 1,2

Fonte galvanisée............ 1,5

Fonte (en moyenne).......... 2,55

Planches jointives $\ldots \ldots \ldots \ldots \ldots \ldots 1,8-9$

Béton ................ $3-30$ (moy. : 9)

Rivée $9-90$ (moy. : 30$)$

(*) N.d.T. - Béton à l'amiante. - On dirait « Eternit» en France.
Drawn tubing, brass, lead, glass, centrifugally spun cement, bituminous lining, Transite, etc. . . . . 0.000,005

Commercial steel or wrought iron ............. $0.000,15$

Asphalted cast iron...... $0.000,4$

Galvanized iron........ $0.000,5$

Cast iron, average....... $0.000,85$

Wood stave .......... $0.000,6-0.003$

Concrete $\ldots \ldots \ldots \ldots \ldots \ldots .0 .001-0.01$

(avg. 0.003)

Riveted steel......... $0.003-0.03$ (avg. 0.01) 
MESURE APPROXIMATIVE DU DÉBTT D'UNE CONDUTTE

L'idée de se servir du « coefficient de vitesse» pour obtenir une excellente estimation du débit d'une conduite à partir d'une seule observation à l'aide d'un tube de Pitot fut proposée par Folsom et IVERSEN, et une méthode modifiée fut proposée par l'auteur au cours de la discussion. C'est cette nouvelle méthode qui fera l'objet d'un examen plus approfondi.

L'installation doit comporter en tête une conduite rectiligne de section uniforme, longue d'environ 20 à 30 diamètres constituant un «tronçon de régularisation » pour l'obtention de l'écoulement normal. A la suite, on trouve un second tronçon dont la longueur doit être suffisante pour provoquer une perte de charge mesurable.

L'appareillage se compose dune part d'un tube de Pitot unique au centre de la conduite, du type

\section{Approximate Measurement of Pipe Flow}

The idea of utilizing the pipe factor to obtain a close estimate of pipe discharge from a single Pitot tube observation was discussed by Fousom and IVERSEN (6) and a modified method was proposed in the discussion by the writer. This method is more completely formulated here.

It requires a preliminary length of straight uniform pipe (of the order of 20 to 30 diameters as a minimum) to serve as a "smoothing length" to establish normal flow, followed by a further length sufficient to give a measurable drop in head. A single central Pitot tube of the type described in the A.S.M.E. Power Test Code for Hydraulic Prime Movers (14) is installed. Two differential gages are used, combined in a three-column gage connected to three

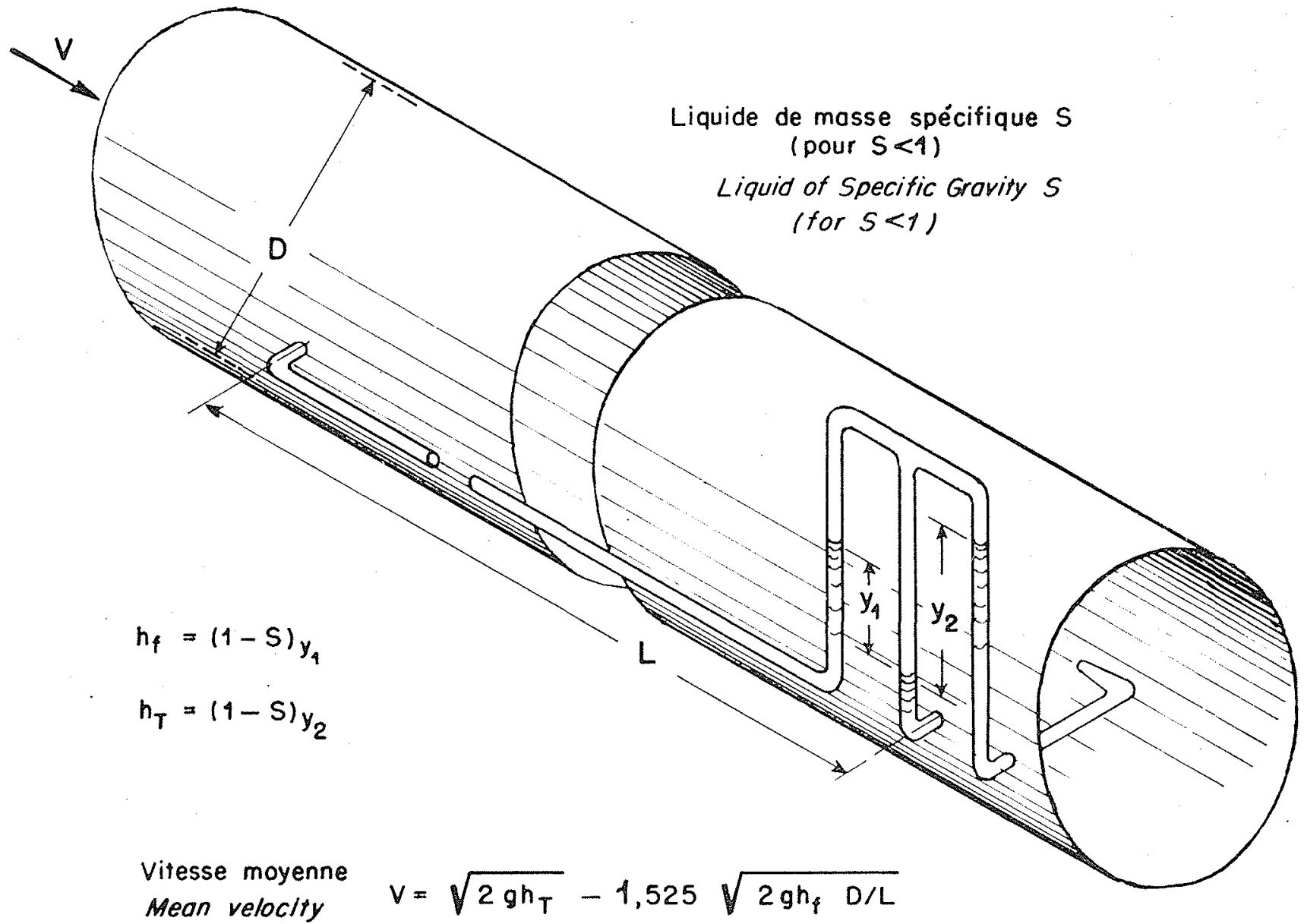

FrG. 3 
décrit dans ASME Pouner Test Code for Hydraulic Prime Movers; d'autre part, de deux manometres différentiels combinés en trois tubes piczométriques réunis à trois points; l'un des manomètres donne la différence de pression $h_{\text {p }}$ entre le lube de Pitot et une prise de pression sur la paroi dans la même section; l'autre donne la perte de charge par frottement $h_{f}$ entre la même prise de pression et une autre située à une distance $\mathrm{L}$ à l'amont (fig. 3 ).

Les relations données ci-dessus permettent alors de déterminer le « coefficient de vitesse», d'où l'on peut tirer la vilesse moyenne et le débit. Lorsque les mesures portent sur de l'eau ou un autre liquide, il est recommandé d'utiliser des manomètres différentiels à 2 liquides avec des tubes fermés afin d'éviter que les ménisques dansent par suite des ondes de pression dans la conduite.

Il a été établi expérimeñtalement que le tube de Pitot enregistre des valeurs trop grandes en écoulement turbulent, et la vitesse au centre est donnée par :

$$
v_{\mathrm{m} i \mathrm{x}}=\mathrm{C} \vee 2 g h_{\mathrm{r}}
$$

dans laquelle $C$ est un coefficient exprimé par Ed. W. et E. Sraw Corr (14) (15) en fonction du «coefficient de vitesse » suivant la relation linéaire :

$$
C=1-0,15\left(1-f_{n}\right)
$$

A partir de la perte de charge $h_{i}$, on obtient, suivant la formule de DARCY :

$$
f=\frac{2 g h_{j} \mathrm{D}}{\mathrm{I} \mathrm{V}^{\prime 2}}
$$

d'où :

$$
f_{p}=\frac{1}{1+1,326 \sqrt{f}}=\frac{\mathrm{V}}{v_{\max }}
$$

Ces équations ćant résolues simultanément, on trouve :

$$
\begin{gathered}
V=-\frac{1}{2} \sqrt{2 g h_{\mathrm{\Upsilon}}}\left[1+\sqrt{\left.1-0,796 \sqrt{\frac{h_{j} \mathrm{D}}{h_{\mathrm{\Gamma}} \mathrm{L}}}\right]}\right. \\
-1,326 \sqrt{2 g h_{f} \mathrm{D} / \mathrm{L} .}
\end{gathered}
$$

Puisque le second terme sous le radical est petil, on peut poser :

$$
\sqrt{1-\mathrm{S}} \cong 1-\mathrm{S} / 2
$$

points, one differential gage giving the differential head $h_{\mathrm{T}}$ between the Pitot tube and a wall piezometer at the same section, the other giving the friction head $h_{f}$ between the same wall piezometer and another located I feet upstream (fig. 3).

Then the relations given above enable us to determine the pipe factor from which the mean velocity and the discharge can be obtained. When measuring the flow of water or other liquid, two-liquid differential gages with elosed columns are recommended to avoid gage column swinging from pressure waves in the pipe system.

Since it has been established by experiment that the Pitol tube slightly over-registers in turbulent flow, the center velocity is given by :

$$
v_{\max }=\mathrm{C} \vee 2 g h_{\mathrm{T}},
$$

in which $\mathrm{C}$ is a coefficient formulated by $\mathrm{Ed}$. W. and E. SHAW Cole $(14,15)$ in terms of the pipe factor, in the linear relation :

$$
C=1-0.15\left(1-f_{p}\right)
$$

From the loss of head $h_{\text {; }}$ we obtain from the Darcy formula :

$$
f=\frac{2 g h_{f} \mathrm{D}}{\mathrm{LV}}
$$

from which :

$$
f_{1}=\frac{1}{1+1.326 \sqrt{T}}=\frac{V}{\nu_{\max }} .
$$

Solving these relations simultaneously yields :

$$
\begin{array}{r}
V=\frac{1}{2} \sqrt{2 g h_{\mathrm{l}}} \mid 1+\sqrt{1-0.796 \sqrt{\frac{h_{f} \mathrm{D}}{h_{\mathrm{T}} \mathrm{L}}} \mid} \\
-1.326 \sqrt{2 g h_{l} \mathrm{D} / \mathrm{L}} .
\end{array}
$$

Since the second term under the radical is small we can put :

$$
\sqrt{1-S} \cong 1-\mathrm{S} / 2
$$

(14) A.S.M.E. Power Test Code for Hydranlic Prime? Movers, 1949 Edition, Par. 147.

(15) "Pitot 'lubes in Large Pipes", by E. W. Cole and F. S. Cole, Trans. A.S.M.E., vol. 61, 1939, pp. $465-475$. 
ce qui donne une approximation très serrée suffisamment exacte dans la pratique :

$$
V=\sqrt{2 g h_{\mathrm{I}^{\mathrm{P}}}}+1,525 \sqrt{2 \mathrm{gh} \mathrm{h}_{\mathrm{f}}} \mathrm{D} / \mathrm{L}
$$

La méthode proposéc peut etre utile toutes les fois qu'on se contente d'une bonne approximation dans la mesure du débit. Ceci évite toutes les complications mécaniques de l'installation d'une batterie de tubes de Pitot mobiles et les pertes de temps considérables qu'entraînent les nombreuses lectures nécessaires à une détermination complète de la courbe de vitesse. giving a very close approximation, sufficiently exact for practical conditions :

$$
\mathrm{V}=\sqrt{2 \mathrm{gh}_{\mathrm{I}}}-1.525 \sqrt{2 \mathrm{gh}_{\mathrm{I}} \mathrm{D} / \mathrm{L}}
$$

The proposed method should be useful whenever a close approximation is sufficient in measuring discharge. It avoids the mechanical complication of installing traversing Pitot tubes and the time-consuming process of taking the many readings needed when the complete velocity curve is measured.

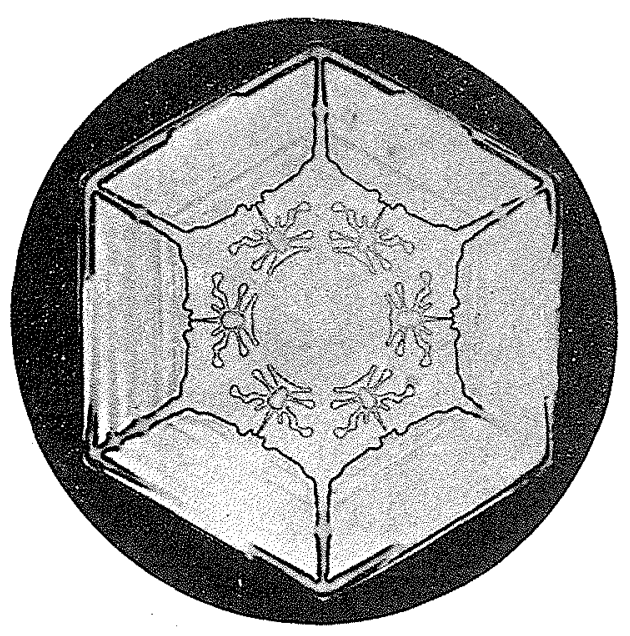

